\title{
Vulvar Cancer Pathologic Regional Lymph Nodes TNM Finding v8
}

National Cancer Institute

\section{Source}

National Cancer Institute. Vulvar Cancer Pathologic Regional Lymph Nodes TNM Finding v8. NCI Thesaurus. Code C139606.

A pathologic finding about one or more characteristics of vulvar cancer, following the rules of the TNM AJCC V8 classification system as they pertain to staging of regional lymph nodes. 